MiMi SHELLER

\title{
TOWARD A CARIBBEAN CULTURAL POLITICAL ECONOMY
}

The Caribbean Postcolonial: Social Equality, Post-Nationalism and Cultural Hybridity. SHALINI PURI. New York: Palgrave Macmillan, 2004. ix +300 pp. (Paper US\$24.95)

Miraculous Weapons: Revolutionary Ideology in Caribbean Culture. JOY A.I. MAHABIR. New York: Peter Lang, 2003. ix + 167 pp. (Cloth US\$ 58.95)

The relation between cultural production and political struggle, and between the aesthetic and the material as expressions of social relations, are absolutely central themes within Caribbean studies in all of its disciplinary and interdisciplinary guises. A key question for the field as a whole is what role it might play in generating new approaches to "cultural political economy," which is emerging as an effective bridging concept at the intersections of anthropology, sociology, economics, political theory, and literary and cultural studies.

Both of the books reviewed here navigate the distinctively Caribbean confluence of two theoretical traditions: a class-centered tradition of anticapitalist political theory and praxis and an aesthetics-centered tradition of anticolonial cultural theory and praxis. Joy Mahabir describes her approach as "historical materialist" while Shalini Puri describes hers as grounded in "Marxist cultural theory." Both also incorporate questions of racial, gender, and sexual hierarchies. Each book engages with a wide range of cultural objects and sites: literary and theoretical texts, musical lyrics and performance, Carnival and public festivities. Thus while focused mainly on literary studies, these texts contribute to the increasingly prevalent transdisciplinary Caribbean cultural studies methodology that encompasses high art and popular culture, performance and politics, theory and history. Indeed, the very relation between the aesthetic and the political is at the core of each author's concerns. 
Equally importantly, each book not only attends to the interaction of African and European cultural elements in the making of Caribbean modernity, but also gives significant weight to the complex inclusion of IndoCaribbean, Chinese-Caribbean, "mixed race," and other underexamined elements. Puri, in fact, makes this central to her argument. The Caribbean Postcolonial is an important contribution to recent debates on hybridity, not because it offers a new grand narrative of Caribbean hybridity (in fact it argues explicitly against such projects) but rather because it demonstrates the need for a carefully historicized, contextual, and conjunctural analysis of discourses of "cultural hybridity." Drawing on the wealth of such discourses in the Caribbean, it examines how different understandings of cultural hybridity have been contorted into very different national and transnational projects, often with conflicting implications for the resolution of racial, ethnic, class, gender, and sexual inequalities.

Poised between "Marxist cultural theory" and Caribbean postcolonial theory, Puri ultimately offers a feminist postcolonial vision of a progressive Caribbean future that might connect "a poetics of hybridity to a politics of equality" (p. 1). In contrast to the tendency in canonical postcolonial theoretical statements to claim hybridity or creolization as either an abstract principle or a new master narrative of the postnational condition that now prevails everywhere, she convincingly calls for a further specification of particular Caribbean elaborations of hybridity (such as mestizaje, creolization, douglarization, jibarismo, etc.) in order to explore "the specificities and histories of each term" (p. 3). This alone makes this a valuable book, which will contribute to teaching in this area.

Part I offers a trenchant critique of contemporary "postnationalist" claims for hybridity and a careful comparative reading of late nineteenth- and twentieth-century discourses of hybridity in the work of Caribbean writers and theorists including Jose Martí, Jose Vasconcelos, Kamau Brathwaite, Derek Walcott, Oswald de Adrade, Wilson Harris, and Edouard Glissant. These chapters, though difficult going at times, reward the reader with a much better understanding of the political, cultural, and historical distinctiveness of different discursive contexts for the circulation of ideas of "cultural hybridity." Puri masterfully compares and contrasts diverse manifestations of (and manifestoes for) magical or marvelous realism, transculturación, mulatto aesthetics, cultural cannibalism, mestizaje, and antillanité as expressions of Caribbean nationalist modernity. She shows how, far from destabilizing the nation as postcolonial theory might imply, these "discursive complexes" in fact have served historically to consolidate the nation by glossing over social inequalities.

In Part II, Puri turns from theory to textual readings of the aesthetics and poetics of hybridity in a wide range of Caribbean texts. Several chapters focus on Afro-European creolization including readings of Glissant's "forced 
poetics," Brathwaite's poetry, Walcott's play Pantomime, and a novel by Erna Brodber. The two final chapters highlight the tension between "creole" and "dougla" hybridities in Trinidad through an analysis of the relation between Afro-Creole Carnival and Indo-Caribbean Hosay, and readings of a novel by Ismith Khan, a chutney-soca song performed by Drupatee Ramgoonai, and a short story by Ramabai Espinet. Finally, Puri calls for a "dougla poetics," which references the "dis-allowed" mixture of Afro-Creole and IndoCaribbean cultural identities, opening up a space of challenge not only to colonial racial orders but also to postcolonial nationalist projects (both AfroCreole and pan-Indian) of purification, separation, and control.

Like other recent work on Black sexual politics, Puri defends the opening up of spaces of public articulation of female sexual agency and acknowledgment of intra-racial inequalities including domestic violence. Her work is distinctive in terms of its combination of theoretical complexity, geographic breadth, and fine-grained analysis of particular texts. It is also valuable because it gives sustained attention to Latin American, Afro-Caribbean, and Indo-Caribbean identities, and the relation between them, while at the same time keeping in sight indigenous peoples, Chinese, and other Caribbean ethnic minorities.

Mahabir's tools for combining class analysis and cultural analysis are somewhat more blunt-edged than Puri's. Her historical materialist perspective "means reading texts to uncover their ideological relationship to history, since they inevitably reflect the economic, social, and political conditions of their production, while offering an ideological view of these conditions" (p. 2). She describes her area of interest as "progressive Caribbean artists" whose work is "centered on class struggle, resistance, and revolution" (p. 2) and includes in her scope the paintings of Wifredo Lam, the poetry of Martin Carter, Edouard Glissant, and Ramabai Espinet, writings by Jacques Roumain and Merle Hodge, and the calypsos of David Rudder. In this body of work she identifies a multiplicity of "resistant discourses" that might be described as underground, subaltern, or as she argues in the first chapter, "contrapuntal."

Although Miraculous Weapons offers a compelling overview of the traditions of resistance and revolution that run through a diverse range of Caribbean artistic works, at times the reading seems overly reductive. For example, Lam's paintings are situated in terms of a brief social history of Chinese indentured migration into Cuba and a brief biographical history including his initiation into Afro-Cuban sacred knowledges and the reception of his work in European avant-garde circles. Mahabir then proposes that Lam's contrapuntal visual rhythm, Afro-Caribbean iconography, and stylistic techniques function as an Althusserian "interpellation" of revolutionary subjects. In a belabored critique of Judith Butler, she argues that the viewer's responses to the paintings are based in "materiality or class relations" rather 
than "psyche and individual existence" (pp. 27-28). Politicized visual culture in this "materialist" interpretation is a direct reflection of ideology, and ideology is a direct reflection of class position.

By drawing together everything from the Haitian Revolution, to marronage and Carnival, Mahabir risks collapsing all Caribbean "resistance" into a singular anticolonial, anticapitalist, anti-imperialist modality, losing some of the nuances and internal conflicts that Puri so carefully identifies in her "conjunctural" and "contextual" readings. In theorizing a common thread of "intellectual marronage" in the poetry of Carter, Glissant, and Espinat, for example, Mahabir contends that she "concretely establishes links between Caribbean texts whose correspondences are often sensed but not yet adequately elaborated within [postcolonial] literary criticism" (p. 36). Yet the notion of marronage as "a cultural and ideological process of anti-imperialism" (p. 38) seems overly broad for the task. Not only does it gloss over the complex social and political histories of various Maroon communities, but the readings of specific poems do not convincingly uphold the argument. It is difficult to follow Mahabir's argument when she ventures into claims that the unmasking of capitalist relations is not stated directly in some poems, but is somehow implied by subterfuge simply by an alignment of the poetic voice with the peasantry and proletariat.

In a chapter on the "Caribbean peasant novel" Mahabir reads Jacques Roumain's Gouverneurs de la rosée through the lens of his communist ideals as a novel about peasant class struggle and Marxist social transformation, rejecting other readings that have emphasized elements of religious or cultural struggle. In the next chapter she reads Merle Hodge's Crick Crack, Monkey as a critique of the postcolonial system of education, positing the academy as a site of class struggle. In both of these chapters, we find a strong program of Marxist-Althusserian literary interpretation and a kind of ahistorical reading of revolutionary class struggle as a uniform project across time and space, whether under colonial capitalism or today's "global capitalism."

Mahabir explicitly rejects Puri's advocacy of a "dougla poetics" on the grounds that "progressive discourses of creolization have left out IndoCaribbean contributions to this process" (p. 58). Yet this is precisely Puri's argument: her concept of the "dougla" is specifically contrasted both to the nationalist ideology of creolization and to the "purist" cultural separatist movements, whether African, Muslim, or Hindu. Mahabir instead argues that the fusion of calypso and chutney rhythms in recent soca music in Trinidad "is used to effectively convey an ideology that is anti-capitalist" (p. 121). In her analysis of David Rudder, Mahabir proposes that rhythm itself plays a transgressive role as a part of a Caribbean culture of resistance and can be analyzed apart from lyrics as "an ideological language" of class struggle. A brief epilogue on Carnival as a "counter-space that threatens capitalist relations" (p. 142) also seems to foreclose the possibility of alternative and contested 
meanings of Carnival in specific times and places, such as those explored by Joseph Roach in Cities of the Dead: Circum-Atlantic Performance.

After reading these two books one is haunted by the larger question of how to understand the relations between art and politics, aesthetics and ideology, cultural production and material relations. This is an old question, but it still elicits continuing debate. In considering the emergence of a "dougla poetics" and its political implications there is a question that begs to be asked after the London bombings of July 2005. Is there not a difference between a performance of chutney soca by a communist artist in Trinidad, a diasporic politics of African and Asian cultural fusion performed in London by Apache Indians, and the strange new cross-fertilization of Caribbean anti-imperialist revolutionary ideologies with the anti-Western terrorist tactics of Al Qaeda practiced by "Jamaican bombers" Richard Reid and Lindsey Germaine?

Mahabir's trans-historical materialism leaves us unable to specify the different ways in which a postcolonial revolutionary ideology grounded in the inequalities of global capitalism might be put to very different uses. Puri's conjunctural understanding helps us to think about how and why each of these cultural projects is distinctive, but her call for a "dougla poetics" is not yet specific enough to enable us to disentangle the relation between aesthetic form and different varieties of dougla politics.

Both authors nevertheless give us a glimpse of an emerging field of Caribbean "cultural political economy" which might allow us to fruitfully bridge nineteenth-century debates about slavery and emancipation, twentieth-century debates about imperialism and national independence, and twenty-first-century debates about the future of the Caribbean. Caribbean history offers a rich and complex legacy of diverse theoretical, political, and cultural projects that have grappled with the nexus of the aesthetic and material realms, as well as the economic nexus of the spiritual and physical realms, the mundane and the transcendent, the bodily and the eternal. Thus Caribbean studies has a crucial contribution to make to enriching contemporary understandings of the ontological projects of the arts and social sciences as a whole.

\section{MIMI SHELLER}

Department of Sociology and Anthropology

Swarthmore College

Swarthmore PA 19081, U.S.A.

$<$ mshelle1@swarthmore.edu> 